\title{
EchoGéo
}

26 | 2013

Varia

\section{Geography of Sand and Gravel Mining in the Lower Mekong River}

First Survey and Impact Assessment

Jean-Paul Bravard, Marc Goichot et Stéphane Gaillot

\section{CpenEdition}

\section{Journals}

Édition électronique

URL : https://journals.openedition.org/echogeo/13659

DOI : 10.4000/echogeo.13659

ISSN : 1963-1197

Éditeur

Pôle de recherche pour l'organisation et la diffusion de l'information géographique (CNRS UMR 8586)

Référence électronique

Jean-Paul Bravard, Marc Goichot et Stéphane Gaillot, « Geography of Sand and Gravel Mining in the Lower Mekong River », EchoGéo [En ligne], 26 | 2013, mis en ligne le 19 décembre 2013, consulté le 31 juillet 2021. URL : http://journals.openedition.org/echogeo/13659; DOl : https://doi.org/10.4000/ echogeo.13659

Ce document a été généré automatiquement le 31 juillet 2021.

EchoGéo est mis à disposition selon les termes de la licence Creative Commons Attribution - Pas d'Utilisation Commerciale - Pas de Modification 4.0 International (CC BY-NC-ND) 


\section{Geography of Sand and Gravel Mining in the Lower Mekong River}

First Survey and Impact Assessment

Jean-Paul Bravard, Marc Goichot et Stéphane Gaillot

This research was made possible with financial support from the Fond Français pour l'Environnement Mondial (FFEM) and was conducted as part of a project run by the Information and Knowledge Management Programme of the Mekong River Commission Secretariat and the World Wide Fund for Nature (WWF) Greater Mekong Progamme. Further thanks go to the surveyors, WWF staff and consultants, as well as to F. Bartsch for editing this article. We also wish to thank two anonymous reviewers for their helpful remarks.

\section{Introduction}

1 Rivers provide developing economies with sand and gravel that are used for the construction of infrastructure and buildings, for elevating land in floodable areas and raising levees against floods, for reclaiming urban land offshore, etc. There are numerous uses for this apparently plentiful, clean and cheap resource and demand is increasing rapidly. In-channel gravel mining developed in the late $1800 \mathrm{~s}$ in industrialized countries for road construction and for concrete. Gravel is of particular value in places where silt and clay are the main resources for construction, as is the case in the lower Mekong basin.

In-channel extraction has a particularly strong impact on river dynamics and ecology. European countries experienced the detrimental impacts of sand and gravel mining as early as the 1950s, notably in northern Italy where large-scale mining provided the raw material for the vast extension of the motorway network. In France, the impact of gravel and sand mining was seen as detrimental at the end of the 1970s, then non sustainable in the 1980s and in-channel mining was finally banned in the early 1990 s. The general causes of bed degradation were studied by Galay (1983) and the negative ecological consequences were documented (Peiry, 1987; Petit et al., 1996; Bravard et al., 1997; Landon et al., 1998; Liébault et al., 1999). After this phase of heightened awareness, 
technical solutions were proposed to river managers (Landon et al., 1998; Bravard et al., 1999a; Bravard et al., 1999b). Similar studies were carried out in the Italian gravel-bed rivers, notably the Arno River and rivers in Northern Italy (Rinaldi et al., 1997; Rinaldi M., Simon A., 1998; Rinaldi et al., 2009). The basic phenomena involved in riverbed incision following gravel and sand extraction have been widely investigated and solutions are based on the restoration of a balanced sediment budget, as demonstrated for instance in California (Kondolf, 1994, 1997). Regulations have been drafted and are now enforced in industrialised countries, but that is not yet the case in the rapidly growing economies of South-East Asia.

The developing countries of Asia today increasingly resort to mining large rivers for sand and gravel, for both construction and land reclamation in flood-prone areas. The Yangzi and Pearl Rivers, both in China, provide examples of the severe impacts affecting the ecology, groundwater level, bank erosion and hydrology. Aggregate extraction shifted from the Yangtze riverbed to Poyang Lake after legislation protecting the river was enforced starting in the year 2000. The rate of sand extraction from Poyang Lake was estimated at 236 million cubic metres per year in 2005 and 2006, i.e. $9 \%$ of Chinese demand. The extraction rate from Poyang Lake was thought to be the highest in the world at that time. As a consequence, the hydrologic buffering of the lake has decreased and biodiversity hot spots are threatened. This is extremely important because Poyang lake is the major expansion area for Yangzi floods (Leeuw et al., 2010a \& b). The positive impacts of sand mining are a reduction of flood damage and improvement of navigation. On the other hand, the estimated 870 million cubic metres of sand excavated between 1986 and 2003 in the rivers of the Pearl basin resulted in severe lowering of river channels, bank instability and threats to infrastructure, changes in the divided flow ratio between various water courses, modification of saltwater intrusion levels and a limitation of the freshwater supply. The extraction rate was much greater than the replenishment rate, a situation aggravated because sediment fluxes depleted dramatically due to the combined effects of declining rainfall, dam construction, water diversion, reforestation and afforestation ( $\mathrm{Lu}$ et al., 2007, Luo et al., 2007).

In Vietnam, economic growth triggered rapid expansion of the construction sector that "required an unexpectedly high quantity of sand", to the point that "sand mining has become a problem in all large rivers [...] that demands a critical solution" due to the lack of regulation (Nguyen, 2011). The branches of the Mekong delta are considered the most impacted because sand production expanded to serve Singapore when Cambodia decided in May 2009 to halt sand exports (Global Witness, 2009 \& 2010). To date, the issue of sediment mining in the Mekong River channel has been approached with caution, at least in reports and scientific publications, because it is a politically sensitive issue with cross-border implications for all the lower Mekong countries. It is not a recent issue because large-scale dredging started in the 1990s along the lower Mekong to reclaim wetlands and bolster the banks of channels, notably around Phnom Penh (Pierdet, 2008a \& b). It is becoming more acute because serious erosion has been observed on the Mekong delta front. This large-scale erosion may be attributed to different factors including the impact of the Lancang chain of dams and the dams built on tributaries, better control of land erosion due to improved agricultural practices and reforestation, climate change and, of course, in-channel extractions which all contribute to reducing sediment fluxes at the river mouth. This assessment is an attempt to provide the first quantification of the volumes of sand and gravel extracted 
from the Mekong River, to locate the extraction sites and to identify trends. The results show that sand mining plays a major role in the sediment budget of the Mekong River and suggest that it may be responsible for part of the retreat of the delta shore.

\section{Sand and gravel resources, domestic and foreign economic demand in the lower Mekong}

5 The Mekong River (known as the Lancang River in China, which means turbulent river) is 4800 kilometres long from its source in Tibet to the delta and drains a basin covering 795000 square kilometres. The basin is geologically and geomorphically diverse, with mountains in the north and along the eastern banks of the river, the Korat plateau occupying the western central section, and low-lying flood plains and the extensive delta system in the lower section. The average annual rainfall along the lower Mekong is 1670 millimetres, while in China it is only $1000 \mathrm{~mm}$ per year. Along the lower Mekong, 85 to $90 \%$ of the rainfall occurs between June and October during the summer monsoon (Gupta, 2007, following the MRC (Lower Mekong Hydrologic Yearbooks), 1997). The total volume of the Mekong monsoon flood (130 days long) averages 65 billion cubic metres at the Chinese border (water from the Lancang River). The total volume increases to an average of 350 billion cubic metres in the lower Cambodian floodplain. The annual suspended-sediment load of the Mekong has been estimated at approximately 160 million tons per year by Walling (2005). About half of this estimated load is derived from the basin in China (Tibetan Plateau and Lancang reach). A substantial, though unquantified portion of the sediment load is sand and fine pebbles transferred as bedload (Plinston and He, 2000).

6 The Mekong River is very complex in terms of sediment fluxes. The scientific literature and the Mekong River Commission reports indicate that most of sediment transit at Pakse is composed of silt and clay (150 to 170 million tons per year on average over the last 50 years). The construction of dams on the Lancang is understood to have decreased the volume, but not modified the composition of the sediment flux. Vast amounts of sand and gravel also exist in the main stem of the Mekong in Northern Laos and sand bars as well as sand from the channel bottom are mined. A study performed in 2011-2013 for WWF (Bravard and Goichot, 2013; Bravard et al., accepted) demonstrated that sand is an important component of the total sediment transit. Sand transits suspended in the water column during floods, but has not been effectively monitored due to the difficulty of vertical integrated sampling during floods. It also transits downstream as bedload and little is known about bedload. Koehnken's work confirms the presence of sand in suspension during floods at different stations of the Mekong (Koehnken, 2012). However, if sand may now be considered a major component of sediment transit to the sea, the precise amount of sand and fine gravel that effectively reaches the seashore remains unknown. On-going sediment monitoring based on improved methods should provide answers. Consequently, the next step is to quantify one of the factors in the sediment budget, i.e. the volume of extracted sediment.

7 Economic demand is high in Thailand and Vietnam. In lowland areas of Cambodia and Vietnam, landfill is widely used to reclaim land and to elevate roads and levees above flood level. In Phnom Penh, the districts close to the Mekong and the Basac Rivers as well as the surrounding natural depressions, called "beng" in the Khmer language, have been raised above flood levels. This use consumes the largest volumes of sand drawn 
directly from the riverbed. Another major consumer of sand extracted from the riverbed is the road network in the delta, which has been significantly extended and flood proofed over the past decade.

8 The demand for sand and gravel from foreign countries has triggered a large exportation business that has also led to more large-scale extractions. Singapore's landmass has increased by $22 \%$ since the 1960 s, partly thanks to river and offshore sand imported from different countries and the city is presently the largest importer of sand in the world (Global Witness, 2009). Since 2000, countries such as Vietnam, Indonesia and Malaysia have banned the exportation of river and offshore sand and the demand is shifting to countries with weaker institutional frameworks, such as Cambodia. In 2009, Cambodia banned dredging after the international controversy following the dredging of the Tatai River, in the Koh Kong Province in South-West Cambodia. However, dredging of the Tatai River continued and supplied Singapore with 6.4 million cubic metres of sand per year, in spite of the rising cost of sand there. Concerning the Mekong river, in 2012, the Cambodian Prime Minister Hun Sen ordered government planners from the Ministry of public works, the Ministry of water resources and the national Mekong committee to draw up a master plan to restore the silted Basac River and shallow areas along the Mekong waterway. This initiative was based on the misconception that dredging would improve navigation conditions with a deeper channel and decrease the risks of bank collapse caused by areas that became shallower after the 2011 flood. As Mr. Hun Sen said, "We must use the river to save the river... We must think about the river as a whole. If we don't resolve [the issues], we don't know what could happen in the future." Cambodia is therefore planning more dredging in order to sell sand to Singapore and China whose national production has been halted for environmental reasons, i.e. reasons that have not yet been taken into account on the Mekong. It was in this context that China made a soft loan to build a terminal in Kien Svay, Kednal province, 30 kilometres downstream of Phnom Penh, that has been used for exporting sand (Radio Free Asia Cambodian service, retrieved 09/03/2012, 22/01/2013).

9 This study provides results from an extensive and systematic survey carried out in the field on the extraction sites. The questions put to technical staffs did not address the complex economy of the resource because the persons questioned were, most often, unaware of the issues. Operators may be small, local structures or they may belong to powerful, private groups or, in some cases, to the State. Most operators would have been unable to answer such questions. Because we needed a homogeneous set of data on the recent history, present geography and expected short-term trends in extraction, we decided to exclude the economy and politics of sand and gravel extraction. These questions may be addressed now using the background information presented in this paper.

\section{Method of the present study}

\section{Context of the study}

This field survey was part of the project titled "Decision aid for generating sustainable hydropower in the Mekong basin. Knowledge of sediment transport and discharges in relation to fluvial geomorphology to detect the impact of large-scale hydropower 
projects", which was carried out from January 2010 to May 2013 and was funded by FFEM (Fond Français pour l'Environnement Mondial). The project was co-managed by the Information Knowledge and Management Programme (IKMP) of the MRC secretariat and the WWF GM. The field work reported in this paper was conducted under the "Geomorphological stability and impact on habitats" task, one of the 21 tasks in the project, and focuses on the lower Mekong River, i.e. the 2400 -kilometre section from the Chinese border to the delta in Southern Vietnam.

\section{Procedure for collecting information}

11 Official statistics from national agencies and the MRC were not readily available, therefore we used a rapid assessment method to evaluate the volumes mined. In Poyang Lake, China, Leeuw et al. (2010a \& b) used an original, remote-sensing approach. Pairs of NIR Aster imaging devices assessed the number, velocity and load of all vessels leaving Poyang Lake, day and night, year long. On the Cau River in Vietnam, the method consisted of field observations, group discussions and consultation of experts on different topics such as financial feasibility and recommendations to mitigate the negative consequences of mining (Nguyen, 2011).

On the Mekong, WWF opted for field investigations. Four teams were appointed to survey the river's main stem in the four lower Mekong countries (Lao PDR, Thailand, Cambodia, Vietnam). The work took place during the low-flow season (February to April 2011 for Laos, Thailand and Cambodia, and May 2012 for Vietnam). The teams conducted surveys based on individual questionnaires for each extraction site. Two types of survey questionnaires were submitted to contractors, depending on the size of the operation.

- Small operations with no interview. The survey included GPS location of the site, categories of sediment extracted (sand, gravel, pebbles), number of full-time staff working on site, types and number of vehicles operating on site (trucks, shovels and loaders, conveyor belts, bucket dredgers and suction dredges).

- Large operation with interview. The same data were collected and questions asked on the number of years of operation, the seasonal calendar of operation, preferential locations of size categories, sediment sizes selected by the company, an estimate of quantities produced annually per category, total quantity extracted each year, demand trend for each category of sediment extracted, changes in quantities extracted over the years, any changes noticed by the operator in the extraction depth (deeper dredging) and concerning in-channel features, an estimate of the increase or decrease in depth, monitoring of activity by local authorities, status of the concession and taxes.

13 The mapping of the results resulted in clustering of extraction sites because many are too close to each other to allow distinct reference points on the basin scale (along the $2400 \mathrm{~km}$ long river course). Sites were clustered when operating in the same $\pm 15 \mathrm{~km}$ long river reach.

14 When volumes at a site were indicated per day, the annual volumes were computed on the basis of 30 days per month multiplied by the number of months of operation. On sites with limited operation, annual volumes were computed on the basis of 15 days per month multiplied by the number of months of operation. In Vietnam (May 2012), annual totals were provided. The mapping of extracted volumes was an important part of the study. Volumes were represented on maps by circles proportional in size to the 
cubic root of the annual extraction figures in cubic meters (Minvielle and Souiha, 2003). This method facilitated measurement reading and avoided disproportionate displays between small sites (very small or non-visible points) and very large sites (large circles).

The maps were drafted using ArcGIS software for the different types of data (Table 1).

Table 1 - Data compiled for drawing the maps

\begin{tabular}{|c|c|c|}
\hline Type of data & Software & Coordinate system \\
\hline Topography & $\begin{array}{l}\text { Compiled using Natural Earth. Free vector and raster } \\
\text { map data @ naturalearthdata.com }\end{array}$ & $\begin{array}{l}\text { Geographic coordinate } \\
\text { system } \quad \text { (projection) : } \\
\text { WGS84 datum }\end{array}$ \\
\hline $\begin{array}{l}\text { Mekong } \\
\text { channel }\end{array}$ & $\begin{array}{l}\text { Compiled using Natural Earth. Free vector and raster } \\
\text { map data @ naturalearthdata.com }\end{array}$ & $\begin{array}{l}\text { Geographic coordinate } \\
\text { system } \quad \text { (projection) : } \\
\text { WGS84 datum }\end{array}$ \\
\hline Tributaries & $\begin{array}{l}\text { Compiled using Natural Earth. Free vector and raster } \\
\text { map data @ naturalearthdata.com }\end{array}$ & $\begin{array}{l}\text { Geographic roordinate } \\
\text { system (projection) : } \\
\text { WGS84 datum }\end{array}$ \\
\hline Watershed & Digitalisation by S. Gaillot & $\begin{array}{l}\text { Geographic coordinate } \\
\text { system (projection): } \\
\text { WGS84 datum }\end{array}$ \\
\hline City & $\begin{array}{l}\text { Compiled using Natural Earth. Free vector and raster } \\
\text { map data @ naturalearthdata.com }\end{array}$ & $\begin{array}{l}\text { Geographic r coordinate } \\
\text { system } \quad \text { (projection) : } \\
\text { WGS84 datum }\end{array}$ \\
\hline Extractions & WWF survey, 2011 & $\begin{array}{l}\text { Geographic coordinate } \\
\text { system } \quad \text { (projection) : } \\
\text { WGS84 datum }\end{array}$ \\
\hline $\begin{array}{l}\text { Hydrographic } \\
\text { network }\end{array}$ & $\begin{array}{l}\text { Compiled using Rivers_in_Southeast_Asia from } \\
\text { Google Earth http://earth.google.com/outreach/ } \\
\text { tutorial_importgis.html }\end{array}$ & $\begin{array}{l}\text { Geographic coordinate } \\
\text { system } \quad \text { (projection) : } \\
\text { WGS84 datum }\end{array}$ \\
\hline Borders & $\begin{array}{l}\text { Compiled using Natural Earth. Free vector and raster } \\
\text { map data @ naturalearthdata.com. }\end{array}$ & $\begin{array}{l}\text { Geographic roordinate } \\
\text { system } \quad \text { (projection) : } \\
\text { WGS84 datum }\end{array}$ \\
\hline
\end{tabular}

16 A Google Earth background was used to position the extraction sites. A simple click opens a file for a cluster of sites, thus making it possible to visualize the intensity of extraction in the river channel in one set of sites. It is important to note that the dates of Goggle images may differ from upstream to downstream on the lower Mekong main stem and are not necessarily synchronous with the dates of the surveys. In some cases, images were obtained before the start of extraction activity. As a result, some of the operations surveyed in 2011 are not visible on the Google images. On the other hand, 
Google images show extraction sites that were not surveyed or are older, thus making it possible to check if large sites were neglected by the surveyors.

\section{Results of this study}

17 The surveys conducted for this study indicate that a total volume of 34.48 million cubic metres or 55.2 million tons (density of 1.6 ton per cubic metre of dry sand) of sediment were extracted from the Mekong main stem in Laos, Thailand, Cambodia and Vietnam in 2011. If we consider only sand, which represents $90 \%$ of the total bulk on average, then the quantity of sand mined amounted to 31 million cubic metres, i.e. 49.6 million tons in 2011.

Gravel and pebbles represent less than $9 \%$ of extracted sediment (Table 2), most of it being gravel (8\%, nearly 3 million cubic metres), for at least two reasons. First, gravel is easier to extract than pebbles and, secondly, cobbles are located and extracted in the steep upper reaches, far from the cities, in areas where demand for construction material is low. It is not surprising that $90 \%$ of extracted sediment (31 million cubic metres) is sand. These results are based on declarations of mining operators. It must be stressed that the study results provide a general estimate of the relative importance of extraction sites that may be considered reliable, however it is likely that the volumes are underestimated by an unknown factor. The discrepancy between reality and estimates may vary from one site to another and from a country to another. Operators have concessions and usually pay fees depending on the amount extracted and would thus be inclined to keep declarations as low as possible. Also, only the main stem of the lower Mekong and two channels of the delta, the Mekong (Tien) and Basac channels (Hieu), were surveyed. The upper Mekong in China, the tributaries and the other channels in the Mekong delta were not surveyed.

Table 2 - Volumes and percentage of grain-size categories per country

\begin{tabular}{|l|l|l|l|l|}
\hline \multirow{2}{*}{ Country } & \multicolumn{4}{|l|}{ Extraction (cubic metres per year) } \\
\cline { 2 - 5 } & Sand & Gravel & Pebbles & Total \\
\hline Laos & 904100 & 10000 & 454500 & 1368600 \\
\hline Thailand & 3677200 & 857740 & 0 & 4534940 \\
\hline Cambodia & 18748503 & 2044940 & 0 & 20793443 \\
\hline Vietnam & 7750000 & 0 & 0 & 7750000 \\
\hline TOTAL & 31079803 & 2912680 & 454500 & $\mathbf{3 4 4 4 6 9 8 3}$ \\
\hline$\%$ & $90 \%$ & $8 \%$ & $1 \%$ & $100 \%$ \\
\hline
\end{tabular}

19 The geography of sediment categories reveals that Cambodia was the largest extractor in 2011-2012 (60\%). Vietnam (22\%) and Thailand (13\%) were respectively $2^{\text {nd }}$ and $3^{\text {rd }}$. Lao PDR produced only $4 \%$ of the total amount of sediment. It must be stressed that this 
result concerns the year 2011 for Laos, Thailand and Cambodia, and 2012 for Vietnam. The ranking and the corresponding volumes may have been different, even in the recent past.

The geography of extraction (Figure 1, Table 3) reveals 1) limited volumes extracted in the mountainous Laotian reach upstream of Vientiane, 2) a long upper reach corresponding to the downstream end of the conveyor belt transporting pebble, gravel and sand bedload and sand in suspension, from Vientiane to Savannaketh, 3) two clusters of sites in the Pakse - Champasak and in the Kratie - Kompong Cham reaches, 4) in the downstream reach, sand extraction occurring all along the Mekong River, except between Kompong Cham and Stoeng Treng. On the local scale, extraction takes place on lateral bars and bank insets upstream, and in the channel itself when the slope decreases and depth increases. The techniques used depend on the seasonal pattern of flow and sediment mining. Upstream of Phnom Penh, gravel and sand are mined during the low-flow season, usually from December/January to May. High bars may be mined longer than low ones. Small extraction sites use mechanical shovels, tractors and light trucks, while bigger sites use pumping dredges and conveyors belts for extraction and have several large trucks. The activity depends on the accessibility of the site by trucks and mechanical shovels. Downstream of Phnom Penh, mechanical shovels operate from artificial levees in shallow areas, and, in deep areas, pumping dredges are the only means to mine sand. With the latter, extraction is possible all year long except during peak flooding. In the delta, sand is dredged with some limited amounts of small-size gravel, which probably originates from ancient layers below the present channel bottom. Due to the unknown depth of dredging, it was not possible to distinguish between the gravelly sand deposited recently and the fossil deposits of the Holocene delta. 
Figure 1- Map of extraction sites along the Mekong River, showing the extracted volumes and grain-size categories

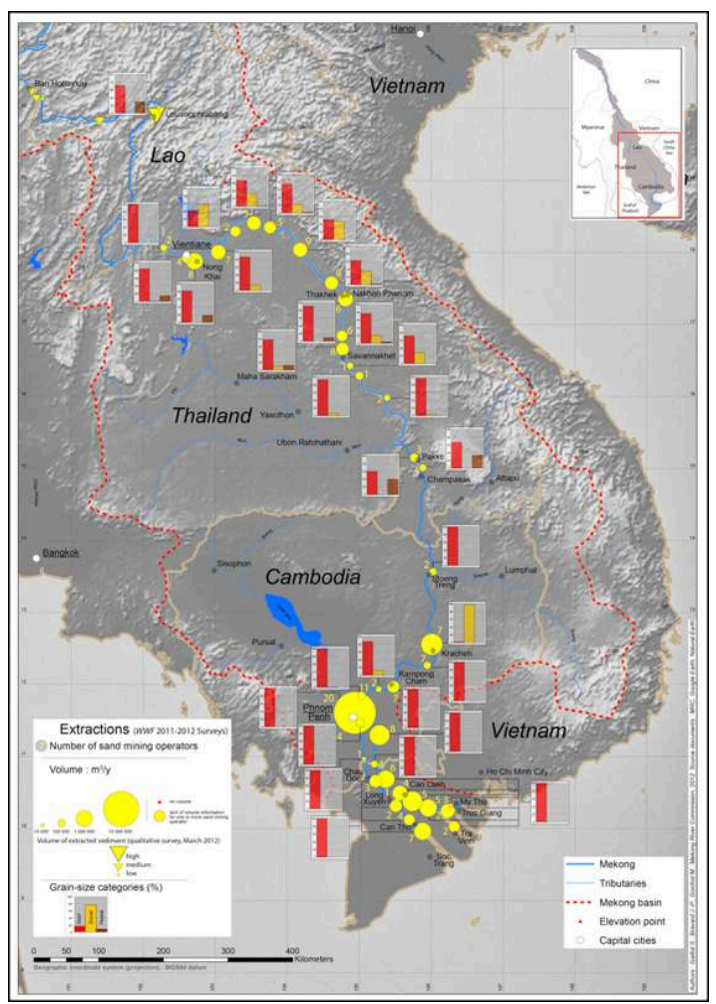

Table 3- Volume extracted by grain-size category in the different functional reaches of the Mekong River

\begin{tabular}{|l|l|l|l|l|}
\hline \multirow{2}{*}{ Reaches } & \multicolumn{4}{|l|}{ Thousands of cubic metres per year } \\
\cline { 2 - 6 } & Sand & Gravel & Cobbles & Total \\
\hline Upstream of Vientiane & 87 & 0 & 7 & 94 \\
\hline Vientiane - Savannaketh & 4154 & 1107 & 367 & 5628 \\
\hline Savannaketh - Champasak & 341 & 29 & 80 & 450 \\
\hline Cambodia upstream of Kompong Cham & 580 & 2038 & 0 & 2618 \\
\hline Kompong Cham - Vietnamese border & 18160 & 7 & 0 & 18167 \\
\hline Delta, Vietnam (Basac + Main channel) & 7750 & 0 & 0 & 7750 \\
\hline Total & 31072 & 3171 & 454 & 34707 \\
\hline
\end{tabular}

21 The number of years of operation indicates that of the 118 sites presently operated, 55 are two-years old and 33 are three-years old (Figure 2, Table 4). This means that the best extraction sites shift along the river and the operators follow them to mine the best sites and particularly the fresh flood deposits. This question concerning work sites was difficult to answer probably because equipment may move across large gravel or 
sand bars, and dredgers may move upstream or downstream. This is probably the case in Vietnam where dredging is the sole mode of sand mining. The fact that extraction sites are mobile partly reflects the slow replenishment of mined areas. On the contrary, stability of operation at a given site indicates that large volumes are stored in the channel and/or the rate of replenishment is high compared to the extraction rate. Data are not complete upstream of Savannaketh, which limits the value of the survey. Four mining sites (in Vietnam) out of 205 had no data and for the eight sites upstream of Luang Prabang (Lao PDR), the volumetric data are qualitative (the survey was visual).

Table 4 - Number of years of operation of operators in the different reaches

\begin{tabular}{|l|l|l|l|l|l|}
\hline Reaches & 1 year & $2-5$ years & $5-10$ years & $>5-10$ years & $>10$ years \\
\hline Upstream of Vientiane & & 1 & & & \\
\hline Vientiane - Savannaketh & & 3 & 2 & & \\
\hline Savannaketh - Champasak & & 3 & & & \\
\hline Cambodia upstream of Kompong Cham & 3 & 4 & 11 & & 3 \\
\hline Kompong Cham to the Vietnamese border & 3 & 14 & 18 & 2 & 12 \\
\hline Channels in the delta, Vietnam & 7 & 30 & 2 & & 15 \\
\hline Total: 118 & 13 & 55 & 33 & 2 & \\
\hline
\end{tabular}

The data on extracted volumes shows a general increase over the past years from downstream of Savannaketh to the Cambodian-Vietnamese border, while extractions have decreased and are expected to continue in the different branches of the delta in Vietnam. Sediment decreases in Vietnam are due to more long-standing dredging. The mobility of dredges along the river may be explained by the depletion of the resource, with operators seeking the last productive sites. A comparative study realized by Brunier et al. (submitted) shows that the depth of the two main channels of the Mekong delta (Mekong and Basac) has increased significantly over the past ten years with consequences for coastal dynamics (Brunier et al., submitted). Extracted volumes are decreasing in the Can Tho reach and in the upstream branches of the delta. However, increases have been noted downstream of Long Xuyen and of Cao Lanh on the lower reaches of the branches (upstream of Truc Giang), which may still have significant resources (palaeo-deposits or replenishment by frequent floods?). On the contrary, operations increase at the upstream end of the delta, in an area of lower pressure on the resource, in particular upstream of Phnom Penh.

The following pictures show different types of gravel and sand extraction in the Mekong 
Photo 1 - An extraction site (shovels and trucks) in a gravel bar downstream of Vientiane. People are collecting white stones (quartz) for decoration

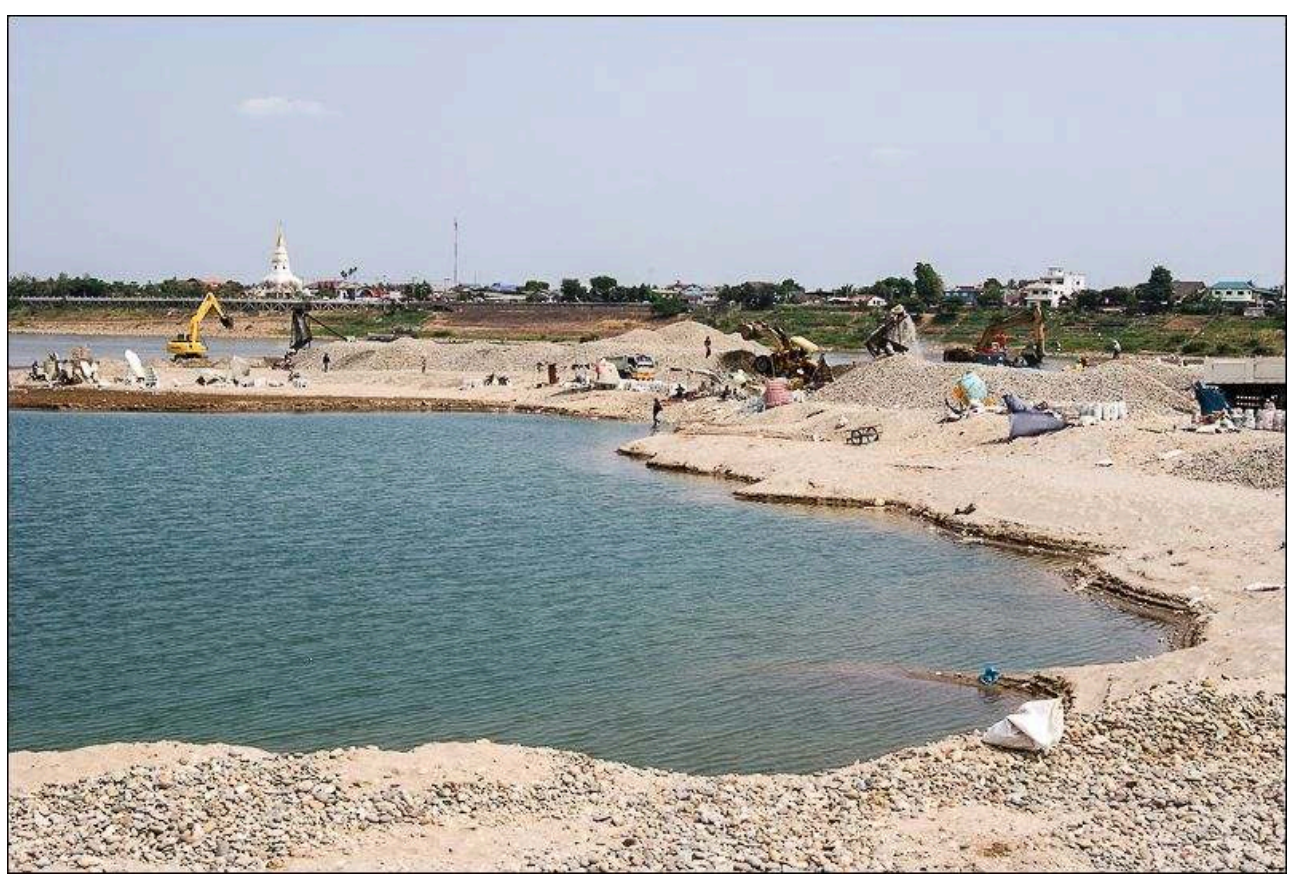

Photo 2 - Aerial view of a newly developing extraction site on a large convex sand bar, at low flow, downstream of Vientiane

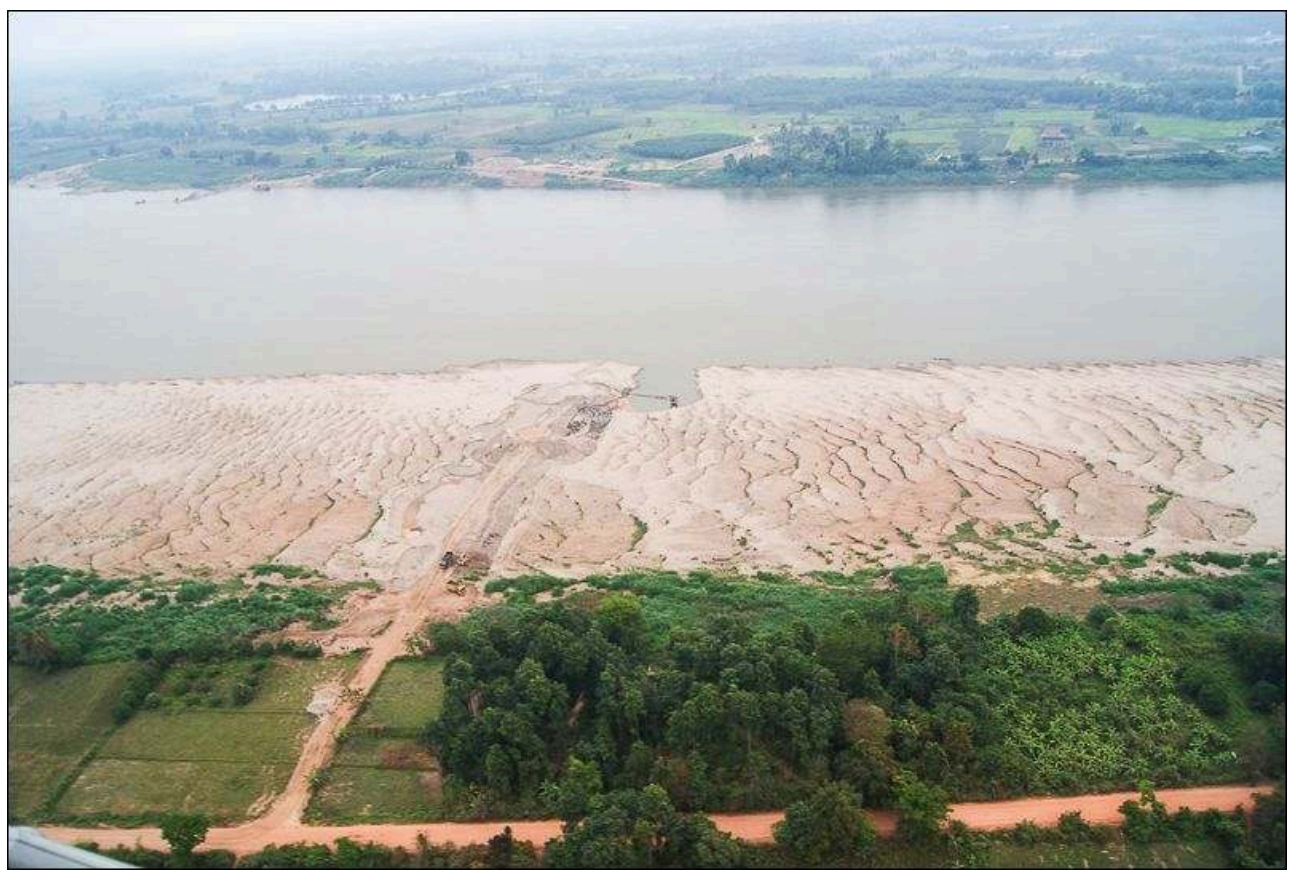


Photo 3 - Dredges pumping sand close to the channel bank to raise an industrial estate on the levee above flood level

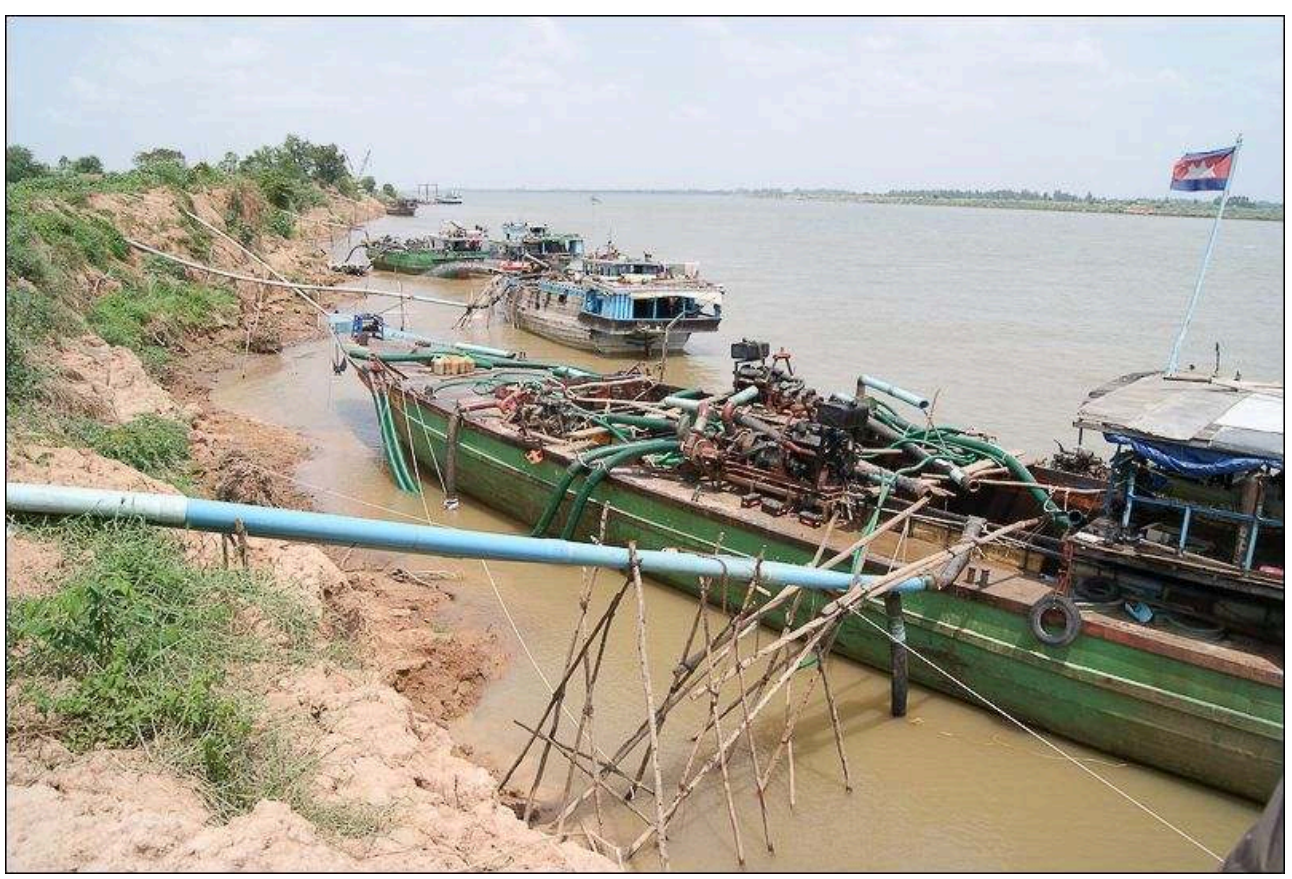

Photo 4 - A bucket dredge in the delta, Mekong channel, Vietnam

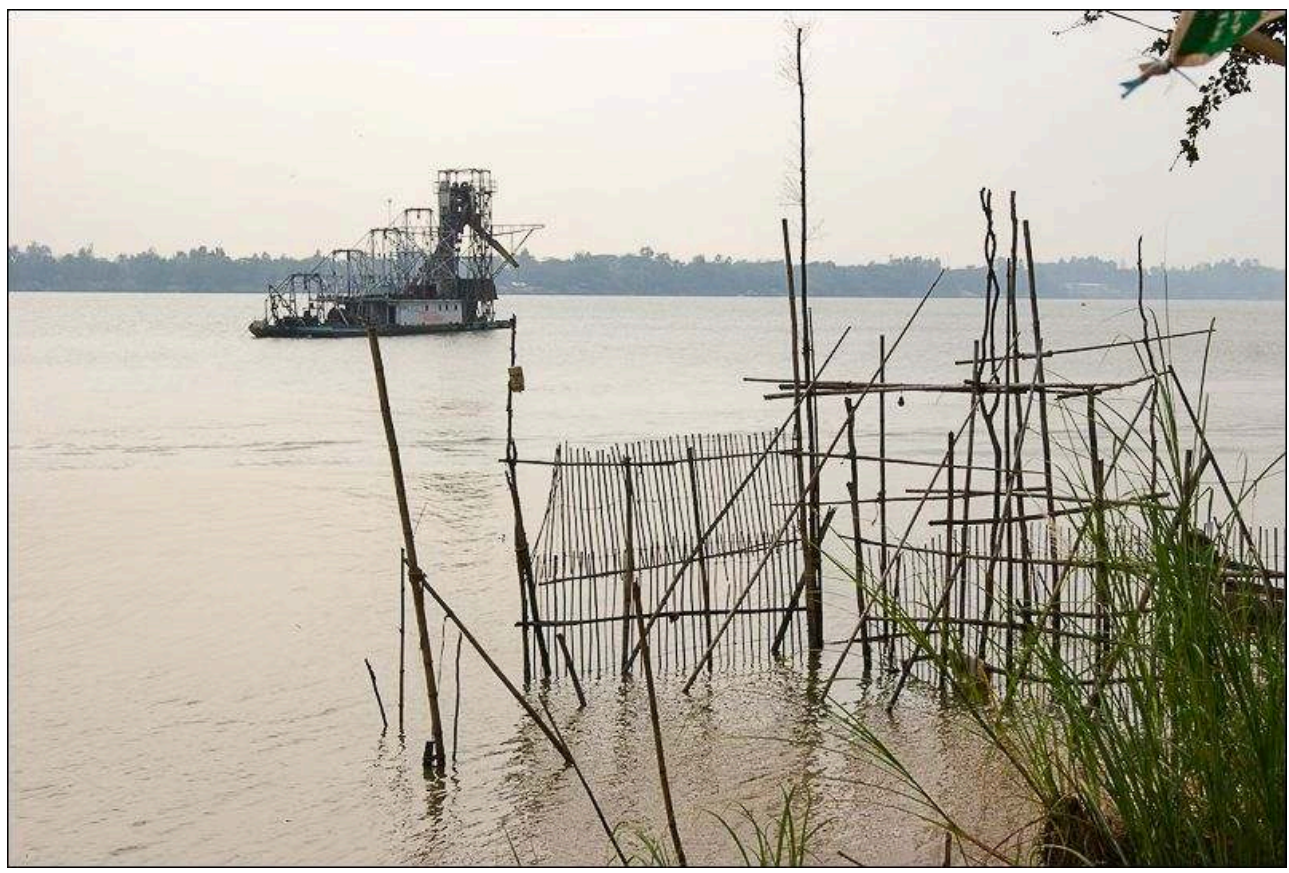


Photo 5 - Barges transporting sand in the Lower Mekong, Ham Long, Vietnam

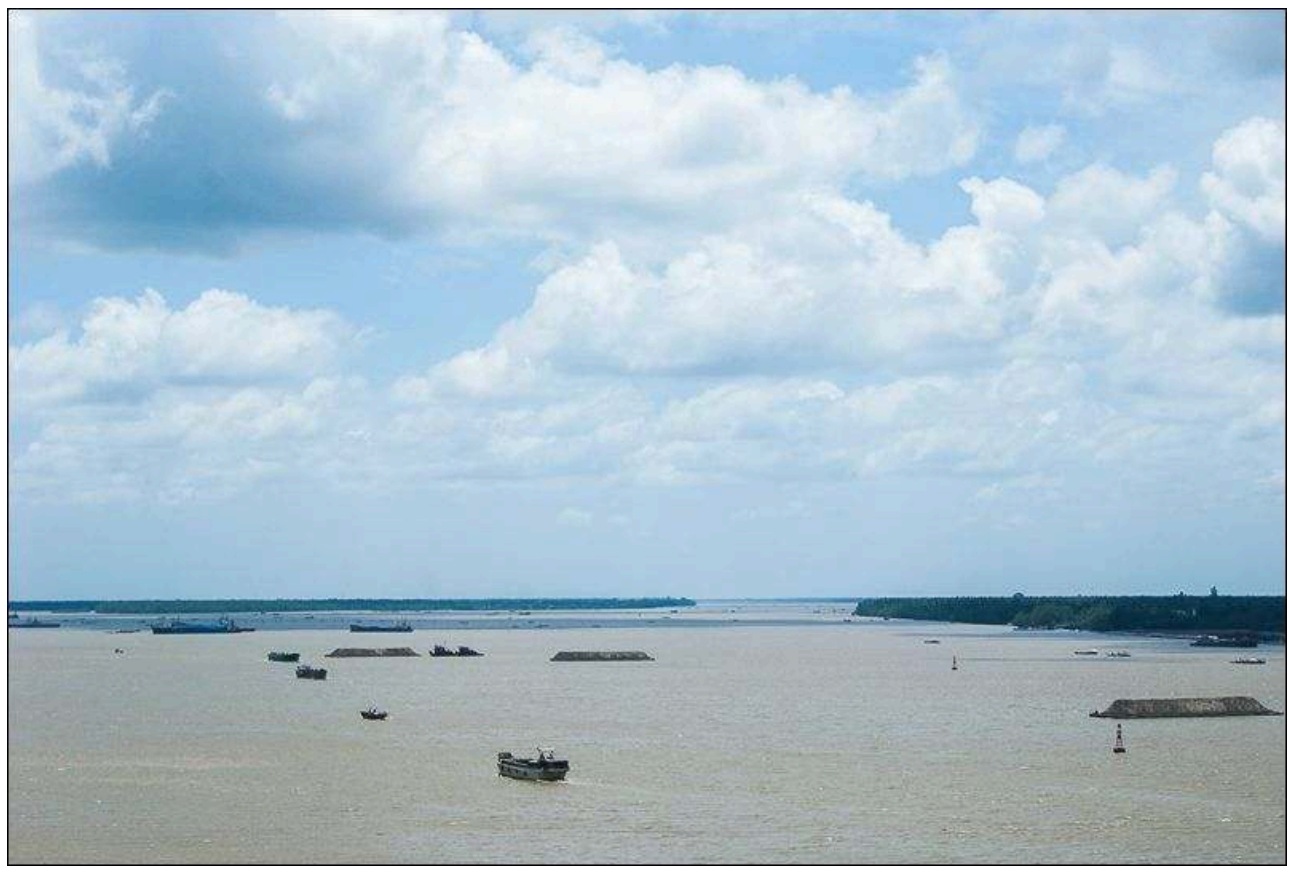

Photo 6 - A Small pumping dredge, Basac channel, Vietnam

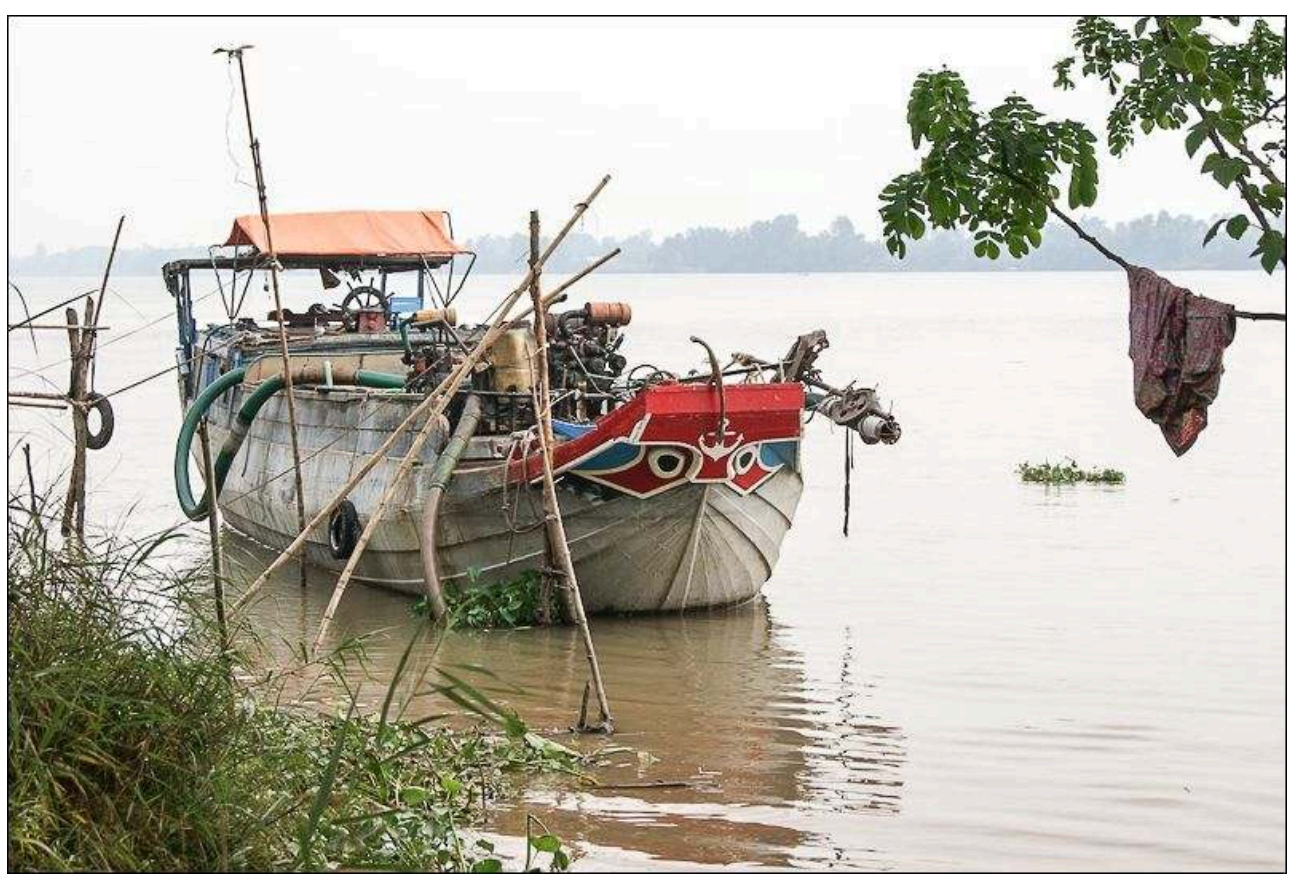

The dredgers themselves foresee a decrease in extractions in the future, which may fit with the decreasing availability of the resource in the Vietnamese part of the delta. The increase of sediment availability indicated by dredgers in the stretch located between Savannaketh and the boundary between Cambodia and Vietnam is significant. Does this mean that the resource has in fact increased or do extractors simply expect an increase in extraction in the area? If the last hypothesis is correct, the situation may be that they have declared the possibility of an increase in the available resource because they hope to negotiate larger concessions in the future. However, this section of the river is 
complex because the operators expect a decrease in the availability of gravel, but an increase in sand extraction. The discrepancy concerning the expected availability of sand and gravel probably reflects the fact that the gravel resource is not renewable while sand is thought to be deposited by repeated floods. While operators see sand and gravel as decreasing resources upstream of Savannaketh, it is worth noting that they do not envision depletion of the sand resource downstream. This may be due to the larger stored volumes in the downstream course.

Overall demand is either increasing on the river scale, or has stabilized in some short reaches. Only in a very limited number of reaches has demand decreased. At this stage, it is difficult to say if demand stability and decreases are due to social-economic reasons, or because the decreasing resource influences the demand and induces a shift toward new areas where the resource is not limited. It is also possible that locally, villagers no longer authorise mining in a self-imposed reduction of the activity because the value of the resource does not compensate the detrimental bank erosion.

\section{Discussion}

\section{Some consequences of gravel mining in the Mekong River}

Because sand and gravel extraction has to date not been considered in and of itself a cause of morphological change and environmental impacts in the Mekong River, we provide here some preliminary information.

- In the absence of a systematic long profile of the Mekong River at low flow, it is not possible to document riverbed incision due to extraction. However, between Kratie and Phnom Penh, we have observed at low flow significant indications of incision on structures built over the past 30 years (piers, bridges over the Mekong and its small tributaries cutting through the levees, the "prek"). Bed incision may locally reach 1 to 3 metres in this reach where the role of reservoir trapping is minimal or inexistent. Further incision, which may be expected giving on-going and planned extraction, may threaten infrastructure.

- In some places, concave banks are confronted with significant lateral erosion, for instance in Saman, downstream of Kratie. According to local residents, faster erosion, threatening villages on the levee, had been triggered by dredging and the village obtained a halt to extraction. However, climate change is also considered responsible for increased bank erosion. According to Darby et al. (2011), ENSO cold phases are associated with earlier onset and enhanced intensity of the monsoon, with increased numbers of intense tropical storm systems and higher rates of riverbank erosion. Without denying this possible cause, we suggest that the impact of dredging is underestimated and should not be masked by climate change.

\section{A necessary reassessment of the Mekong sediment load}

The actual extracted volume and tonnage ( 34.5 million cubic metres, or 55.2 million tons) are probably higher and exceed the yearly discharge of sediment because the riverbed has been severely altered with the deepening of the channel. The suspendedsediment discharge of the Mekong River is commonly estimated to be 145 to 160 million tons at Kratie (Milliman and Meade, 1983) and is thought to be (primarily) composed of "fines", i.e. silt and clay. The share of suspended sand in this total is 
unknown, but thought to be limited. Moreover, bedload contribution remains unknown. We suggest that the sediment discharge of the Mekong is underestimated because sand transiting as bedload and as suspended load has not been assessed. That being said, recent evaluations of suspended-sediment discharge incorporate some sand in an unknown proportion, which may reduce the discrepancy. From all the above, we draw the following conclusions concerning the actual sediment discharge of the Mekong.

1. Suspended-sediment discharge, which presently coincides with total sediment load, exceeds 145 to 160 million tons because part of the sand transiting as suspended load is not monitored (Bravard et al., accepted). Our results show that the true total sediment discharge of the Mekong is underestimated. Under natural conditions, part of the sand discharge at the sea is suspended load and part is bedload, depending on the flood discharge and on the energy available on the reach scale. Bedload is a component of sediment discharge that is not presently taken into account. It should be evaluated because this component of the sediment budget is severely altered by extraction. A conservative estimate of sand in suspension and sand transiting as bedload could add 10 to 30 million tons to the common estimate of 145 to 160 million tons of suspended sediment.

2. Coarse and medium-size sand is presently unable to reach the river mouth and the seashore because numerous deep sand pits opened by dredging operations trap the sand (Brunier et al., submitted). Sand originating from suspension and rolling along the bottom is trapped, then dredged. However, part of the fine sand may still transit as suspended load and reach the mouths of the Mekong, but in unknown quantities.

3. If the conservative figure of 56 to 57 million tons of extracted sediment per year is accepted, then to what extent is sediment discharge affected? It must be stressed that the total sediment discharge of the Mekong is probably underestimated because part of the bedload and suspended load (sand) is illegally extracted from the channel.

- Unfortunately, sand has been poorly monitored since the beginning of TSS monitoring and thus is not considered an important element in the sediment budget. As a result, the average figure of 145 to 160 million tons per year is not impacted by extraction because only silt and clay are taken into account.

- However, the modification of the channel geometry indicates that the cumulative impact of extraction from the river for at least the past 20 years has exceeded and probably still exceeds the input of sediment from the river basin, in which case it is not possible to add the 50 million extracted tons to the generally accepted figure for sediment discharge. It would be useful to obtain more detailed data on extracted volumes which may have increased, but we may suppose that extraction from the channel has for years exceeded upstream inputs and induced an imbalance in the sediment budget to the detriment of the seashore.

- The impact of Chinese dams has been seen as an important component in the altered sediment budget. Indeed, they may affect fine suspended load transiting from upstream without deposition before the low lands of Cambodia. However, they have not affected sand transport yet because it is still possible to remove considerable amounts of sand from in-channel landforms in the upper mountain reaches of Laos. The impact of the Lancang dams is probably delayed concerning medium and coarse sand and part of the fine sand.

\section{Mined rivers of South-East Asia}

Sand mining is a growing activity in an increasing number of rivers in South-East Asia. A documented case study in Northern Vietnam revealed that mining activities have 
persisted even though they contradict public regulations concerning extraction levels. Licensed companies often exceed the legal extraction limits and even resort to illegal practices to the point of threatening public guards (Nguyen, 2011). In China, Chen et al. (2006) report that "the involvement of local criminal gangs and official corruption were the main difficulties for the ban on illegal sand extraction". The increasing demand for sand and the high profits explain why, in many river basins, mining is no longer under control.

The Malaysian Ministry of natural resources and environment has published official guidelines on managing sand mining in rivers (2009). The guidelines recommend surveying the river, but not disseminating any information documenting changes and the cumulative effects of sand mining. In the event of a drop in riverbed levels on the reach scale, extraction "could be limited" to minimize the impact. It is also stipulated that extraction could be forbidden for environmental reasons. In Sri Lanka, Gunaratne (2010) stated that the Asian tsunami of 2004 produced a boom in construction and that one third of all extractions are illegal. Considering the impacts, the most important being saltwater intrusion from the sea into the lowermost parts of the delta branches due to deeper channels and decreased inland water velocity, Punaradne recommended mining sand from alternative sources, notably offshore, a solution that causes other problems. On the Yangtze River, Chen et al. (2006) showed that sand extraction from the mid-lower Yangtze has increased rapidly since the 1980s, with a rapid decrease in sediment discharge from the Yangtze River into the sea. They proposed that the sites and amounts permitted for in-channel sand extraction be re-evaluated in light of the new sediment budget after closure of the Three-Gorges Dam. It is necessary to explore the use of alternative materials in order to reduce the demand for natural sand while meeting the market needs for social-economic development.

\section{Conclusion}

This paper provides an initial quantitative evaluation of the volumes of sand and gravel extracted from the Lower Mekong main stem in 2011-12 and of the trend. The main objective was to raise awareness among scientists and decision-makers of the importance of sand mining for the management of river-related natural resources and biodiversity conservation. The dissemination of scientific data concerning the impacts of extraction worldwide and more specifically of preliminary results obtained in the Mekong basin should increase pressure upon managers for better regulation. This first assessment calls for better monitoring not only of sand and gravel transport, but also of future extraction. This should also be complemented by a wider set of perspectives including social, economic and political - supported by much finer analysis of the actors involved in the extraction industry (how they operate and how the revenue of this lucrative business is distributed) in order to propose better regulation and regional cooperation.

31 Undeniable efforts have been made by the Lower Mekong countries during the past decade to improve transborder management of river resources. But the lack of quantitative assessments and the fact that governance institutions in place still have their limitations has been a barrier to the establishment of an effective regulatory framework. Lessons from other countries, including the institutional and legal tools developed there, and the self-imposed corporate-responsibility guidelines and 
standards that industry players are setting up to ensure the sustainability of their activity can all contribute to faster mobilisation of civil society and decision-makers.

The concept of integrated river-basin management is now widely acknowledged and it implies that hydropower development and sand mining cannot be managed independently. In the case of the Mekong basin, these two aspects are probably among the most important in a basin-wide development plan.

\section{BIBLIOGRAPHIE}

Bravard J.-P., Amoros C., Pautou G., Bornette G., Bournaud M., Creuzé des Chatelliers M., Gibert J., Peiry J.-L., Perrin J.-F., Tachet H., 1997. River incision in Southeastern France : morphological phenomena and ecological impacts. Regulated Rivers: Research and Management, 13, p. 75-90.

Bravard J.-P, Goichot M., 2013. Decision Support for Generating Sustainable Hydropower in the Mekong Basin. Part 1 : Knowledge of sediment transport and discharges in relation to fluvial geomorphology for assessing the impact of large-scale hydropower projects. Part 2: Extractions in the Mekong River channel WWF. Report for MRC, Decision support for generating sustainable hydropower in the Mekong basin, Vientiane.

Bravard J.-P, Goichot M., Tronchère H., 2013. An assessment of sediment-transport processes in the Lower Mekong River based on deposit grain sizes, the CM technique and flow-energy data. Geomorphology, DOI: 10.1016/j.geomorph.2013.11.004

Bravard J.-P., Kondolf G.M., Piégay H., 1999a. Environmental and societal effects of channel incision, and remedial strategies. In S.E. Darby et A. Simon (eds), Incised River Channels: Processes, Forms, Engineering and Management, Chichester, John Wiley \& Sons Ltd, p. 303-341.

Bravard J.-P., Landon N., Piégay H., Peiry J.-L., 1999b. Principles of engineering geomorphology for managing channel erosion and bedload transport, examples from French rivers. Geomorphology, 31, 1-4, p. 291-311.

Brunier G., Anthony E., Goichot M., Provansal M., Dussouillez Ph., submitted. Recent morphological changes in the Mekong and Basac river channels, Mekong Delta, and the strong impact of riverbed mining. Geomorphology.

Chen X., Zhou Q., Zhang E., 2006. In-channel sand extraction from the Mid-Lower Yangtze channels and its management problems and challenges. J. Environ. Planning Management, 49, p. 309-320.

Darby S.E., Trieu H.Q., Carling, P., 2011. Influence of ENSO on Lower Mekong River bank erosion. International Conference on the Status and Future of the World's Large Rivers, 11-14 April 2011, Vienna (Summary).

Galay V., 1983. Causes of river bed degradation. Water Resources Research, 19, p. 1057-1090.

Global Witness, 2009. Country for Sale. How Cambodia's Elite has Captured the Country's Extractive Industries. London, Global Witness Ltd, 72 p. 
Global Witness, 2010. Shifting sand. How Singapore's Demand for Cambodian Sand Threatens Ecosystems and Undermines Good Governance. London, Global Witness Ltd, 48 p.

Gunaratne L.H.P., 2010. Policy Options for Sustainable River Sand Mining in Sri Lanka. Sri Lanka, Department of Agricultural Economics and Business Management, Faculty of Agriculture, University of Peradeniya.

Gupta A., 2007. The Mekong River: morphology, evolution, management. In Gupta A. (ed.), Large Rivers. Geomorphology and Management, Wiley \& Sons, Chichester, p. 435-455.

Koehnken L., 2012. IKMP Discharge and Sediment Monitoring program Review, Recommendations and data Analysis. Part 2: data analysis and preliminary results. Phnom Penh, MRC.

Kondolf G.M., 1994. Geomorphic and environmental effects of instream gravel mining. Landscape and Urban Planning, 28, p. 225-243.

Kondolf G.M., 1997. Hungry water: effects of dams and gravel mining on river channels. Environmental Management, 21, p. 533-551.

Landon N., Piégay H., Bravard J.-P., 1998. The Drôme river incision (France): from assessment to management. Landscape and Urban Planning, 43, p. 119-131.

Liébault F., Clément P., Piégay H., Landon N., 1999. Assessment of bedload supply potentiality from the tributary watersheds of a degraded river: the Drôme (France). Arctic, Antarctic and Alpine Research, 31 (1), p. 108-117.

Leeuw J. de, Georgiadou Y., Kerle N., Gier A. de, Inoue Y., Ferwerda J., Smies M., Narantuya D., 2010a. The function of remote sensing in support of environmental policy. Remote Sensing, 2, p. 1731-1750.

Leeuw (de) J., Shankman D., Wu G., Boer (de) W.F., Burnham J., He Q., Yesou H., Xiao J., 2010b. Strategic assessment of the magnitude and impacts of sand mining in Poyang Lake, China. Regional Environmental Change, 10, p. 95-102.

Lu X.X., Zhang S.R., Xie S.P., Ma P.K., 2007. Rapid channel incision of the lower Pearl River (China) since the 1990s as a consequence of sediment depletion. Hydrol. Earth Syst. Sci., 11, p. 1897-1906.

Luo X.L., Zeng E.Y., Ji R.Y., Wang C.P., 2007. Effects of in-channel sand excavation on the hydrology of the Pearl River Delta, China. Journal of Hydrology, 343, p. 230-239.

Milliman, J D, Meade, R H., 1983. World-wide delivery of river sediment to the oceans. Journal of Geology, 91, p. 1-21.

Ministry of Natural Resources and Environment, 2009. River Sand Mining Management Guideline. Kuala Lampur, Publ. Department of Irrigation and Drainage, 85 p.

Minvielle E., Souiah S.-A., 2003. L'analyse statistique et spatiale. Paris, Éditions du Temps, 284 p. Nguyen M. D., 2011. River Sand Mining and Management : a Case of Cau River in Bac Ninh Province, Vietnam. Singapore, EEPSEA Research Reports, $61 \mathrm{p}$.

Peiry J.-L., 1987. Channel degradation in the middle Arve River. Regulated Rivers, 1, p. 183-88.

Petit F., Poinsart D., Bravard J.-P., 1996. Channel incision, gravel mining and bedload transport in, the Rhône river upstream of Lyon, France ("canal de Miribel"). Catena, 26, p. 209-226.

Pierdet C., 2008a. Marges aquatiques et politiques urbaines au centre de Phnom Penh (Cambodge). Autrepart, 1, n 45, p. 123-136. 
Pierdet C., 2008b : Les temporalités de la relation ville-fleuve à Phnom Penh : la fixation d'une capitale fluviale par la construction d'un système hydraulique (1865-2005). Thèse de doctorat en Géographie, Université Paris I Panthéon-Sorbonne.

Rinaldi, M., Simon, A., Billi, P., 1997. Disturbance and adjustment of the Arno River, Central Italy II: quantitative analysis of the last 150 years. In Wang, S.S.Y., Langendoen, E.J., Shields Jr., F.D. (Eds.), Management of Landscapes Disturbed by Channel Incision. University of Mississippi, Oxford, p. 256-261.

Rinaldi, M., Simon, A., 1998. Bed-level adjustments of the Arno River, central Italy. Geomorphology, 22 , p. 57-71.

Rinaldi M., Simoncini C., Piégay H., 2009. Scientific strategy design for promoting a sustainable sediment management: the case of the Magra River (Central - Northern Italy). River Research and Applications, 25, p. 607-625.

Walling D., 2005. Evaluation and analysis of sediment data from the Lower Mekong River. Phnom Penh, Unpublished report for the Mekong River Commission.

\section{RÉSUMÉS}

L'extraction des sables et graviers en rivière a augmenté dans les pays développés depuis au moins le milieu du XX $\mathrm{XX}^{\mathrm{e}}$ siècle, en particulier pour la construction (béton) et les remblais (voies ferrées et routières, conquête de terrains en zone inondable, plates-formes en mer). Dans les 30 dernières années, ce phénomène a connu une grande expansion dans les pays en développement tels que la Chine, l'Inde et dans d'autres pays asiatiques à croissance rapide. Les impacts négatifs de l'extraction des ressources fluviales sont bien documentés en Europe et aux États-Unis depuis le début des années 1980 et des études sont maintenant disponibles sur les extractions en Asie du Sud-est et notamment en Chine.

Le Bas Mékong et ses bassins tributaires sont des hauts lieux de la biodiversité mais ils ont connu un essor considérable de la construction des barrages, en particulier sur le cours chinois du Mékong, le Lancang. L'enjeu actuel le plus important dans le bassin du Mékong est sans aucun doute la menace qui pèse sur les côtes du delta car l'importance de ce dernier est remarquable en termes de sécurité alimentaire pour les populations en forte croissance du Vietnam et du Cambodge. Les raisons les plus souvent citées pour expliquer le recul du delta sont le piégeage des sédiments qui se fait dans les retenues du haut bassin et le changement climatique. Les extractions de sable et gravier dans le chenal du Mékong et sur ses affluents n'ont pas encore été prises en considération.

Cet article fournit la première évaluation de l'extraction des ressources en granulat sur les $2400 \mathrm{~km}$ du cours principal du Bas Mékong, de la frontière chinoise au delta. Le Fonds Mondial pour la Nature (WWF) a réalisé un relevé en 2011-2012. Des entretiens systématiques ont été réalisés dans les quatre pays du bas Mékong pour évaluer les types de matériaux extraits, les techniques utilisées, les volumes extraits, les tendances enregistrées ces dernières années et les changements attendus dans la géographie des extractions. Les résultats révèlent que le volume annuel de sable et de gravier extrait, en dépit d'une sous-évaluation évidente, excède le volume de sable et de gravier transporté par le fleuve. Les résultats soulignent aussi l'importance considérable de ce facteur dans les changements géomorphologiques et écologiques enregistrés dans les différents tronçons du Mékong et dans son delta.

Sand and gravel mining from rivers has increased throughout the developed countries since at least the mid-1900s, for construction (concrete) and for landfill (railways, motorways, land 
reclamation in flooded areas, offshore reclamation). Over the past 30 years, this phenomenon has spread due to the economic development of countries such as China, India and other fastgrowing economies of South-East Asia. The detrimental impacts of aggregate extraction have been well documented in Europe and in the U.S. since the early 1980s and studies are now available on extraction in S.E. Asia, notably in China.

The lower Mekong River and its tributary watersheds are hotspots for biodiversity, but have seen considerable dam construction, particularly along the Lancang, the upper course of the Mekong in China. Currently, the most important issue in the Mekong basin is certainly the threat to the delta coastline because of its importance in terms of food security for the growing populations of Vietnam and Cambodia. The reasons most often cited to explain the retreat of the delta are the trapping of sediment in the existing upstream reservoirs and climate change. Sand and gravel mining in the Mekong River bed and in the tributary channels has not been taken into consideration to date.

This paper provides the first assessment of sediment extraction along the 2400 -kilometre channel of the main stem of the lower Mekong River, from the Chinese border to the delta. The World Wide Fund for Nature ran a survey in 2011-2012. Systematic interviews assessing the types of aggregates, extraction techniques, extracted volumes, trends over the past years and the expected changes in the geography of extraction were carried out in the four countries drained by the Lower Mekong. The survey results reveal that the yearly volume of sand and gravel extracted, despite its undervaluation, exceeds the transported volume of sand and gravel in the Mekong sediment load. The results also highlight the extreme importance of this factor in the geomorphologic and ecological changes of the Mekong reaches and the delta.

\section{INDEX}

Keywords : sand and gravel extraction, impact of sand and gravel mining, Mekong River, SouthEast Asia

Mots-clés : extraction de sable et gravier, impact des extractions de granulat, Mékong, Asie du Sud-Est

\section{AUTEURS}

\section{JEAN-PAUL BRAVARD}

Jean-Paul Bravard, jean-paul.bravard@orange.fr, University of Lyon, France.

\section{MARC GOICHOT}

Marc Goichot, Marc.Goichot@wwfgreatermekong.org, World Wide Fund for Nature (WWF), Greater Mekong, Vientiane, Lao PDR.

\section{STÉPHANE GAILLOT}

Stéphane Gaillot, stephane.gaillot@mairie-lyon.fr, Service Archéologique Municipal, Lyon, France. 